\title{
Diabetic Ankle Fractures: A Review of the Literature and an Introduction to the Adelaide Fracture in the Diabetic Ankle Algorithm and Score
}

\author{
Joshua Yee, ${ }^{1}$ Anand Pillai, ${ }^{2}$ and Linda Ferris ${ }^{3}$ \\ ${ }^{1}$ Department of Orthopaedics and Trauma, The Queen Elizabeth Hospital, 28 Woodville Road, \\ Woodville West, SA5011, Australia \\ ${ }^{2}$ South Manchester University Hospital, South Moor Road, Wythenshaw, Manchester, UK \\ ${ }^{3}$ The Queen Elizabeth Hospital, Woodville West, SA5011, Australia \\ Correspondence should be addressed to Joshua Yee; joshua.yee@icloud.com
}

Received 21 April 2013; Revised 16 October 2013; Accepted 17 October 2013; Published 5 January 2014

Academic Editor: Padhraig O’Loughlin

Copyright (c) 2014 Joshua Yee et al. This is an open access article distributed under the Creative Commons Attribution License, which permits unrestricted use, distribution, and reproduction in any medium, provided the original work is properly cited.

\begin{abstract}
Diabetics who have acquired an ankle fracture may be easily missed given their atypical presentation. As such, it is not infrequently seen that these patients are either initially misdiagnosed or ineffectively managed resulting in unnecessary hospital length of stay and procedures. Multiple review articles and retrospective studies have been previously published in the literature, but complete guidelines to assist in accurate diagnosis and cost-effective management for this complex problem do not currently exist. Through a critical analysis of the current literature, a proposed diagnostic and management algorithm and scoring system that can be used to quantify risks in the surgical management are presented for consideration.
\end{abstract}

\section{Introduction}

Both diabetes and ankle fractures are increasing in incidence worldwide. In 2003, it was estimated that 194 million people in the world have been diagnosed with diabetes and this is predicted to exponentially increase to over 333 million by 2025 [1]. Ankle fractures are amongst the most common injuries encountered by orthopaedic surgeons, with its incidence on the rise in parallel with general life expectancy $[2,3]$. Extrapolated from this data, the incidence of diabetic ankle fractures will inevitably increase. There is, however, a lack in a standardized diagnostic and treatment guidelines for diabetic ankle fractures. Additionally and not uncommonly, diabetic ankle fractures have been misdiagnosed resulting in delayed management. For these reasons, we propose a diagnostic and management algorithm that incorporates a quantitative scoring system in hope to achieve a practical approach to this complex and challenging problem.

\section{Materials and Methods}

Publications were identified by conducting a comprehensive keyword search of Medline, EMBASE, and CINAHL databases between the months of September 2010 to March 2011 by the primary author (Joshua Yee). Search terms included "diabetes," "ankle," and "fracture." Available abstracts of all articles (i.e., no date restriction to search results) published in the English language in the above databases searched within the above timeframe where included for initial review to determine suitability. Inclusion criteria for full-text review were that articles must be relevant to diabetic ankle fracture diagnosis and management. Manual search of the all the references in the full-text publications was also completed to further identify additional publications for potential inclusion. All included full-text publications for review were further defined as either a notable or supportive. A publication was defined to be notable if the study design (i.e., cohort, retrospective, case control, and case series) and level of prognostic strength (i.e., level IV or higher) were met. Notable publications were subjected to further critical analysis. Exclusion criteria were the following: publications not published in English; all conferences, lectures, review articles, and publications that were neither published nor published in the above databases. Duplicate results that occurred in different databases were truncated to a single result. 


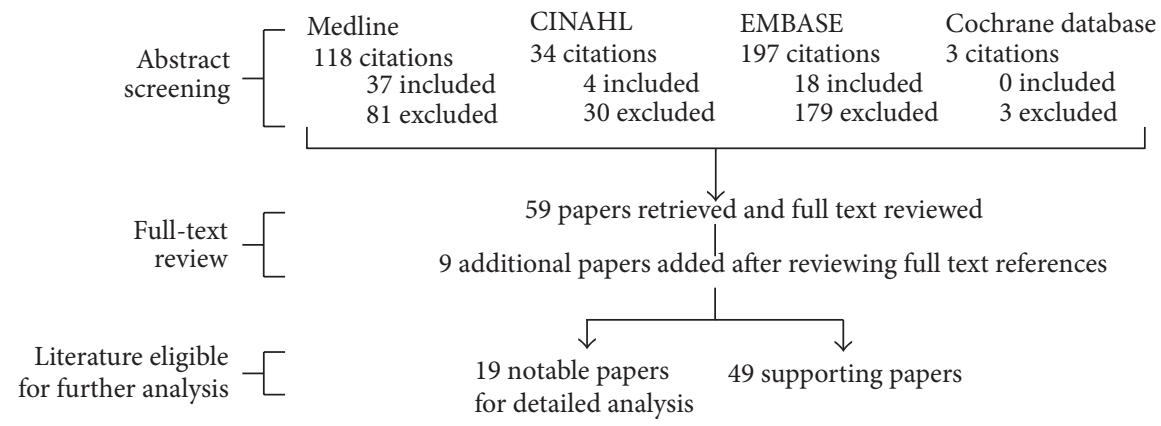

FIGURE 1: Literature review results in detail.

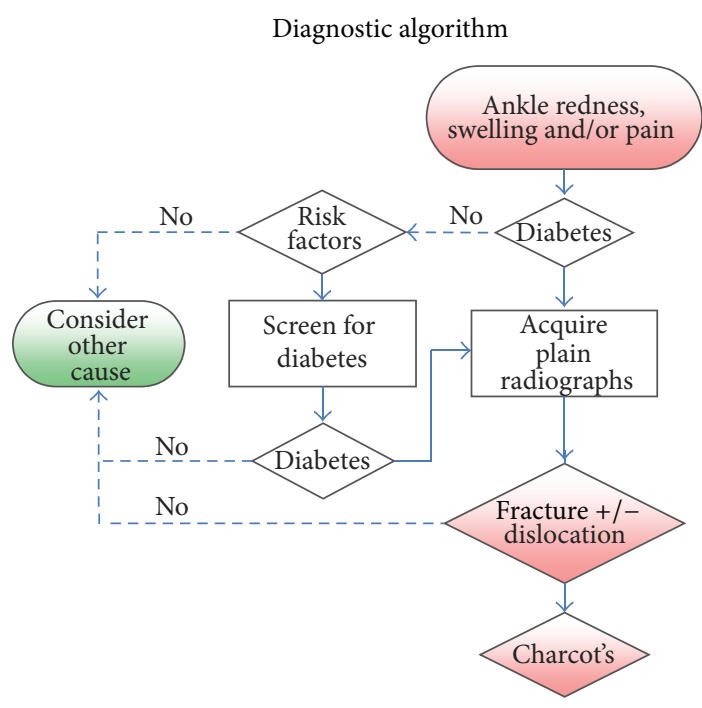

FIGURE 2: AFDA diagnostic algorithm.

\section{Results}

A total of 352 abstracts were initially screened. From these abstracts, 59 articles met our inclusion criteria for further full text review. 293 articles were excluded. Nine additional articles were found after reviewing all the full-text references (Figure 1). Nineteen notable papers were identified for further critical analysis (Tables 1 and 2). From these results, we propose the Adelaide Fracture in the Diabetic Ankle (AFDA) algorithm and score (Figures 2 and 3, Table 3).

\section{Discussion}

The AFDA algorithm consists of two parts: a diagnostic and management part (Figures 2 and 3), having its own respective goals. The diagnostic part is targeted for primary care physicians and nurse practitioners with a goal to accurately and timely provide a diagnosis to any presentation of ankle redness, swelling, and/or pain; and if such a presentation is encountered, the algorithm progresses to assess or screen for the presence and risks for diabetes.

Risk factors for diabetes include previous history of impaired glucose intolerance; high-risk ethnic groups (i.e.,
TABLE 1: Notable publications in detail.

\begin{tabular}{lcl}
\hline Study type & $\begin{array}{c}\text { Total number } \\
\text { of studies }\end{array}$ & Publication details \\
\hline Review articles & 3 & Wukich and Kline [2] \\
& Prisk and Wukich [18] \\
Myerson and Edwards [6]
\end{tabular}

Asian, African, and Hispanic); positive family history or gestational diabetes; age greater than or equal to 45 with either a body mass index (BMI) greater or equal to 25 or presence of hypertension; and established cardiovascular risk factors or disease. If risk factors are present, screening for diabetes is suggested using either HBAlc (greater or equal to $6.5 \%$ ), two-hour plasma glucose (greater or equal to $11.1 \mathrm{mmol} / \mathrm{L}$ ) during an oral glucose tolerance test, or fasting blood glucose (greater or equal to $7.0 \mathrm{mmol} / \mathrm{L}$ ) [4].

If the presence of diabetes has been excluded, other causes of ankle redness, swelling, and/or pain should be considered, which can include: gout, infection, septic arthritis, deep vein thrombosis (DVT), and haemarthrosis $[5,6]$. Furthermore, if there is an absence of systemic signs of infection (i.e., fever, elevated white cell count, or CRP), then infection is unlikely [6]. 


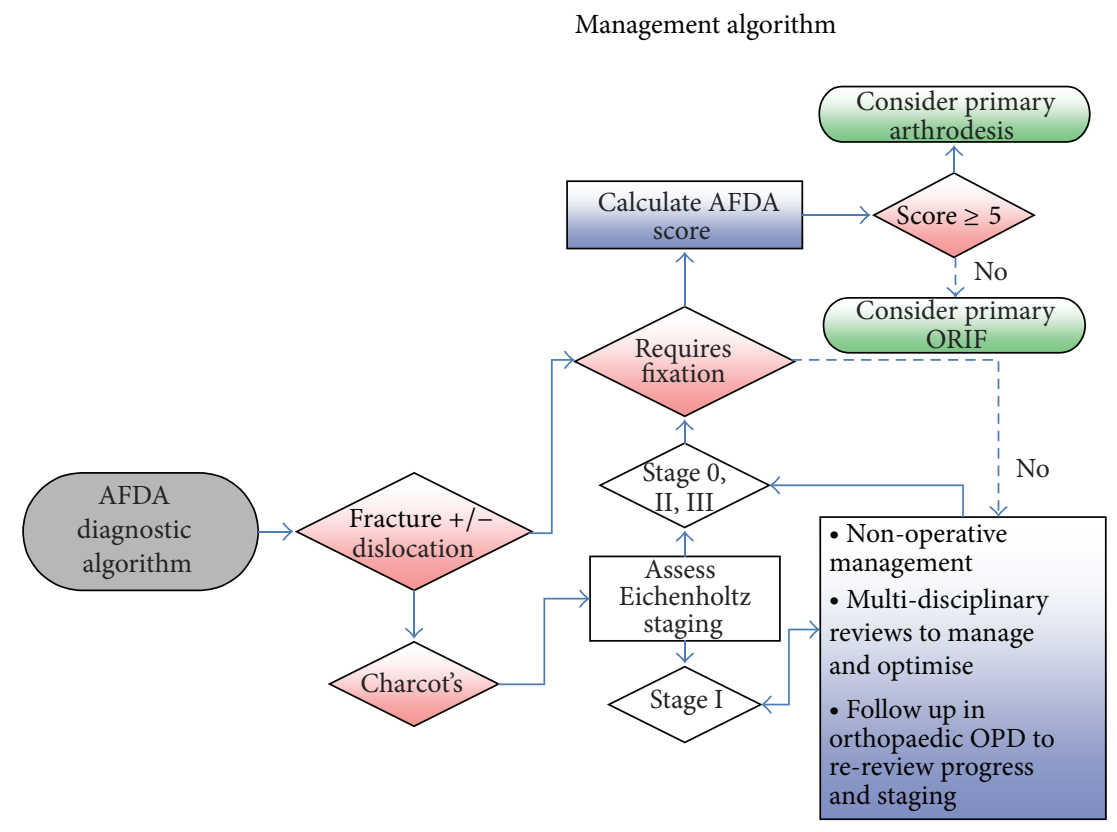

FIGURE 3: AFDA management algorithm.

Since the introduction of the Ottawa ankle rules [7], there has been a significant increase in cost efficiency to plain radiograph usage in assessing acute ankle injuries. However, there has been question of whether the Ottawa ankle rules apply in diabetics $[8,9]$. If there is a history of diabetes or newly diagnosed diabetes, we suggest that plain radiographs can be acquired independent of the Ottawa ankle rules. This should be interpreted for presence of a fracture, dislocation, and/or Charcot's arthropathy. Because of the possibility of an insensate lower limb, the patient's history may be difficult to elicit which has occurred first: the fracture or acute Charcot's. However, if any of these are present, the AFDA management algorithm and score can be applied.

The AFDA management algorithm and score will assist the treating specialist in the optimal decision making for managing diabetic ankle fractures. If a fracture requires fixation, the AFDA score (Table 3) can be considered to differentiate between managing it as a primary ORIF or primary rigid fixation/arthrodesis. Ganesh et al. [3] have, in an analysis of a nationwide inpatient database, concluded that there are significant increases in in-hospital length of stay and costs for diabetics with ankle fractures compared with nondiabetics. Having a decision from the outset can potentially decrease these factors and, furthermore, allow the patient to return to their usual activities earlier and save them from unnecessary revision surgery. Rigid fixation/arthrodesis is reserved for patients who are at high risk of amputation or failure if primary ORIF is used. Comparing techniques of rigid fixation/arthrodesis is beyond the scope of this discussion, but options include retrograde intramedullary nailing $[10,11]$, posterior blade plate [12], external ring fixators [13], and cross-screw techniques [14].

If Charcot's arthropathy is present in conjunction with the diabetic ankle fracture, Eichenholtz's [15] staging should also be considered. As Eichenholtz stage I has traditionally been considered to be the acute fragmentation stage, the current literature recommends that this stage can be managed nonoperatively in the interim, with nonweight bearing and serial total contact casting. Additionally, frequent followup and further patient optimization through multidisciplinary review and management can be considered. Endocrine input for consideration of intravenous bisphosphonate therapy (i.e., Pamindronate) has been shown to inhibit the increased osteoclastic activity that weakens bones during this acute stage $[16,17]$. Optimization of diabetic control, nutrition, and vascular status whilst this stage progresses will likely achieve a better outcome. Once Eichenholtz's staging progresses outside of stage I, progression for fixation consideration is suggested. Postoperatively and independent from the surgical fixation technique, the literature suggests that all patients undergo prolonged nonweightbearing for 12 weeks, protected or partial weight bearing for another 8 to 12 weeks, with frequent outpatient followup with plain radiographs initially fortnightly for the first six weeks, then monthly thereafter [18].

The AFDA scoring system (Table 3 ) is based on assessable patient factors. Two points have been allocated to factors more readily seen in the notable publications to suggest either poor outcomes of standard internal fixation or better outcomes with rigid fixation/arthrodesis. A Semmes Weinstein monofilament $10 \mathrm{~g} / 5.07$ at the plantar aspect of either the great toe, first, third, or fifth metatarsal head can be used to assess presence of neuropathy [18]. Presence of vasculopathy can be defined as peripheral oxygen saturations consistently less than $95 \%$ or an ABI of less than 0.65 [19]. Obesity can be defined as a BMI of greater than 30. Smoking has not been included as a factor because it increases general surgical risk, independent of fixation technique. 
TABLE 2: Critical analysis of the notable publications.

\begin{tabular}{|c|c|c|c|c|}
\hline Study type & $\begin{array}{l}\text { Authors, year, and } \\
\text { location origin }\end{array}$ & $\begin{array}{c}\text { Prognostic } \\
\text { evidence strength }\end{array}$ & Patient details & Relevant findings \\
\hline \multirow{4}{*}{ Cohort study } & \multirow{4}{*}{$\begin{array}{l}\text { Guo et al. [20] } \\
\text { China, } 2009\end{array}$} & \multirow{4}{*}{ Level II } & $\begin{array}{l}\text { (i) Retrospectively selected } 72 \\
\text { patients ( } 36 \text { preoperatively } \\
\text { neglected diabetes, } 36 \\
\text { nondiabetic controls) with } \\
\text { closed ankle fractures between } \\
01 / 03 \text { and } 09 / 07\end{array}$ & \multirow{4}{*}{$\begin{array}{l}\text { (i) Increased incidence of infection, } \\
\text { nonunion, and Charcot's } \\
\text { arthropathy } \\
\text { (ii) No significant difference in } \\
\text { AOFAS and Bray's ankle score } \\
\text { between two groups }\end{array}$} \\
\hline & & & $\begin{array}{l}\text { (ii) Recall of patients for } \\
\text { prospective review over } 12 \\
\text { months }\end{array}$ & \\
\hline & & & $\begin{array}{l}\text { (iii) Managed either } \\
\text { nonoperatively and } \\
\text { operatively }\end{array}$ & \\
\hline & & & (iv) Mean age 54.4 & \\
\hline \multirow{2}{*}{$\begin{array}{l}\text { Retrospective } \\
\text { study }\end{array}$} & $\begin{array}{l}\text { SooHoo et al. [21] } \\
\text { USA, } 2009\end{array}$ & Level II & $\begin{array}{l}57,183 \text { operatively managed } \\
\text { ankle fractures }(1,219 \text { were } \\
\text { complicated diabetic ankle } \\
\text { fractures) }\end{array}$ & $\begin{array}{l}\text { Significant increase in complication } \\
\text { rates (wound infection, revision } \\
\text { operation, and BKA) in complicated } \\
\text { diabetic group }\end{array}$ \\
\hline & $\begin{array}{l}\text { Ganesh et al. [3] } \\
\text { USA, } 2005\end{array}$ & Level II & $\begin{array}{l}\text { 160,598 nationwide ankle } \\
\text { fractures ( } 9174 \text { diabetic ankle } \\
\text { fractures) between } 1988 \text { and } \\
2000\end{array}$ & $\begin{array}{l}\text { Diabetics had significant increase in } \\
\text { in-hospital mortality, complications, } \\
\text { length of stay, and cost }\end{array}$ \\
\hline \multirow{10}{*}{ Case control } & $\begin{array}{l}\text { McCormack and Leith } \\
\text { [22] } \\
\text { Canada, } 1998\end{array}$ & Level III & $\begin{array}{l}\text { (i) } 52 \text { patients ( } 26 \text { diabetic, } 26 \\
\text { control) with closed ankle } \\
\text { fractures between } 04 / 90 \text { and } \\
01 / 99\end{array}$ & $\begin{array}{l}\text { Significant increase in } \\
\text { complications in both nonoperative } \\
\text { and operative fixation in diabetics }\end{array}$ \\
\hline & & & (ii) Mean age 61 (43-78) & \\
\hline & $\begin{array}{l}\text { Jones et al. [23] } \\
\text { USA, } 2005\end{array}$ & Level III & $\begin{array}{l}\text { (i) } 84 \text { patients ( } 42 \text { diabetic, } 42 \\
\text { control) } \\
\text { (ii) Mean age } 57.1\end{array}$ & $\begin{array}{l}\text { Significant increase in long-term } \\
\text { bracing in diabetics (mean age } 53.6 \text {, } \\
\text { insulin dependant, mean duration } \\
\text { of DM } 20.3 \text { years, and history of } \\
\text { Charcot's) }\end{array}$ \\
\hline & $\begin{array}{l}\text { Flynn et al. [24] } \\
\text { Puerto Rico, } 2000\end{array}$ & Level III & $\begin{array}{l}\text { (i) } 98 \text { patients with closed } \\
\text { ankle fractures ( } 25 \text { diabetic, } 73 \\
\text { nondiabetic) between } 01 / 88 \\
\text { and } 31 / 97\end{array}$ & \multirow{2}{*}{$\begin{array}{l}\text { Significant increase in postoperative } \\
\text { infection in diabetic group (up to } \\
\text { five times), especially with factors: } \\
\text { nonoperative management, poor } \\
\text { glycaemic control, and neuropathy }\end{array}$} \\
\hline & & & $\begin{array}{l}\text { (ii) Mean age } 44 \text { (nondiabetic) } \\
\text { and } 60 \text { (diabetic) }\end{array}$ & \\
\hline & \multirow{4}{*}{$\begin{array}{l}\text { Blotter et al. [25] } \\
\quad \text { USA, } 1999\end{array}$} & \multirow{4}{*}{ Level III } & $\begin{array}{l}\text { (i) } 67 \text { surgically treated ankle } \\
\text { fractures in patients ( } 21 \\
\text { diabetic, } 46 \\
\text { nondiabetic/control) between } \\
03 / 85 \text { and } 10 / 96\end{array}$ & $\begin{array}{l}\text { (i) Significant increase in } \\
\text { postoperative complication in } \\
\text { diabetic group ( } 43 \% \text { versus } 15 \%) \text {, } \\
\text { particularly in the insulin } \\
\text { dependent }\end{array}$ \\
\hline & & & $\begin{array}{l}\text { (ii) 4/21 Webber C, 17/21 } \\
\text { Webber B }\end{array}$ & \multirow{2}{*}{$\begin{array}{l}\text { (ii) } 2 \text { cases of postoperative } \\
\text { Charcot's arthropathy in diabetic } \\
\text { population }\end{array}$} \\
\hline & & & (iii) Mean age 55 (diabetic & \\
\hline & & & $\begin{array}{l}\text { group) and } 53 \\
\text { (nondiabetic/control group) }\end{array}$ & (iii) No diabetic subgroup analysis \\
\hline & $\begin{array}{l}\text { Kristiansen [26] } \\
\text { Denmark, } 1983\end{array}$ & Level III & $\begin{array}{l}30 \text { patients (10 diabetic, } 20 \\
\text { nondiabetic/control) }\end{array}$ & $\begin{array}{l}\text { Significantly increase in wound } \\
\text { infection ( } 60 \% \text { versus } 10 \%) \text { and } \\
\text { hospitalization in diabetics (17 } \\
\text { versus } 9 \text { days) }\end{array}$ \\
\hline
\end{tabular}


TABLE 2: Continued.

\begin{tabular}{|c|c|c|c|}
\hline Study type & $\begin{array}{l}\text { Authors, year, and } \\
\text { location origin }\end{array}$ & $\begin{array}{c}\text { Prognostic } \\
\text { evidence strength }\end{array}$ & Patient details \\
\hline & \multirow{3}{*}{$\begin{array}{l}\text { Bibbo et al. [27] } \\
\text { USA, } 2001\end{array}$} & \multirow{3}{*}{ Level III } & $\begin{array}{l}\text { (i) } 59 \text { patients with isolated } \\
\text { ankle fractures ( } 13 \text { diabetic, } 46 \\
\text { nondiabetic/control) }\end{array}$ \\
\hline & & & $\begin{array}{l}\text { (ii) Mean age } 55.1 \text { (diabetic), } \\
40.2 \text { (nondiabetic/control) }\end{array}$ \\
\hline & & & $\begin{array}{l}\text { (iii) Mean followup } 46 \text { months } \\
\text { (diabetic) and } 32 \text { months } \\
\text { (nondiabetic/control) }\end{array}$ \\
\hline
\end{tabular}

Costigan et al. [28]

USA, 2007

Ayoub [14]

Egypt, 2008

Holmes and Hill [29]

USA, 1994

Case series
Level IV fracture over an 8-year period

(ii) Mean age 49.5

(iii) Average followup 4.1 years

(i) 17 patients with Charcot arthropathy undergoing

Level IV tibiotalar arthrodesis

(ii) Mean age 61.6 (57-69)

(iii) Mean followup 26 months

(i) Assesses relationship of early diagnosis and treatment in 18 patients with diabetic ankle or foot

Level IV fracture/dislocations between

(ii) Mean age 55

(iii) Mean followup 27 months

(i) 83 tibial pilon fractures (14 diabetic, 68 nondiabetic) between 01/2005 and 06/2007

(ii) Mean age 47.3

(iii) Length of followup 14.5 months (diabetic) and 12.3 months (nondiabetic)

(i) 14 open ankle fractures in 13 patients with diabetes between 01/01/1981 and

White et al. [31]

USA, 2003

Schon et al. [32]

USA, 1998

Low and Tan [33]

Singapore, 1995
Level IV $31 / 12 / 2000$

(ii) Mean age 54 (29-80)

(iii) Mean followup 19 months (iv) $9 / 13$ patients were insulin dependent

28 diabetic neuropathic ankle fractures (15 undisplaced, 13 displaced)

(i) 93 surgically treated ankle fractures (83 nondiabetic, 10 diabetic) between 01/1992 and 06/1993

Level IV (i) 84 diabetic patients with previous ORIF of an ankle $05 / 85$ and $05 / 90$

Relevant findings

(i) Increased complication rate in diabetics compared to nondiabetics (46\% versus $17 \%$ )

(ii) None required amputation/arthrodesis

(iii) No information on presence of diabetic complications

Significant increase in complications in diabetics with peripheral neuropathy and peripheral vascular disease

Fusion rates were higher in patients with $\mathrm{O}_{2}$ saturations $>95 \%$, decreased BMI, absence of peripheral neuropathy

$11 / 20$ had a delay in diagnosis with average time of 1 month between onset of symptoms and diagnosis

Significant increase in postoperative complications including infection (71\% versus $19 \%$ ) and nonunion/delayed union (43\% versus $16 \%$ )

9/14 developed wound complications, $6 / 14$ had below knee amputations (4 of these were at least Gustilo Class III open fractures), and $3 / 14$ healed

(i) Undisplaced ankle fractures are amenable to nonoperative management without significant complications

(ii) Of the 13 displaced ankle fractures, high risk of malunion/nonunion if standard ORIF is used

(i) 5 reported cases of infection (all diabetics)

(ii) 2/5 requiring below knee

(ii) Mean age 67.5

(iii) Mean followup 16.2 months amputation, with at least $1 / 5$ having a history of peripheral neuropathy 
TABLE 3: AFDA scoring system.

Two points each

One point each

(i) Peripheral neuropathy/loss of protective sensation

$[2,23,24,28,33]$

(ii) Presence of vasculopathy $[2,14,28]$

(iii) Insulin dependence with poor compliance [23-25, 30]

(iv) Previous or coinciding history of Charcot's arthropathy

in any joint $[2,14,23]$

With the use of AFDA algorithm, it can hopefully provide a standardized approach and guide to management for diabetic ankle fractures. The scoring system, in particular, can assist in objectively quantifying risk for both the patient and affected ankle joint so as to allow the treating specialist to have confidence in achieving the best possible outcome. As the score increases, the risks of failure in standard fixation methods increase and consideration of more robust and rigid fixation techniques or fusion should be incorporated. From our review of the literature, we suggest that if the patient scores five or more, rigid fixation/arthrodesis should be considered from the outset. If rigid fixation/arthrodesis fails, despite adequate measures in hope for an optimal outcome, amputation can be considered.

The current evidence of which AFDA is derived from is based primarily on heterogeneous study designs and our center's experience. As such, it will require further validation reviews or trials, incorporating followup and functional outcome scores. Once validated, AFDA can be used as a protocol and research tool for the diagnosis and management of diabetic ankle fractures.

\section{Conflict of Interests}

The authors declared that they have no conflict of interests.

\section{Authors' Contribution}

Anand Pillai and Linda Ferris are equally contributed.

\section{References}

[1] Health N, (Australia) MRC, Barr ELM, Institute ID. AusDiab 2005: the Australian diabetes, obesity and lifestyle study: tracking the accelerating epidemic: its causes and outcomes. International Diabetes Institute, 2006.

[2] D. K. Wukich and A. J. Kline, "The management of ankle fractures in patients with diabetes," Journal of Bone and Joint Surgery A, vol. 90, no. 7, pp. 1570-1578, 2008.

[3] S. P. Ganesh, R. Pietrobon, W. A. C. Cecílio, D. Pan, N. Lightdale, and J. A. Nunley, "The impact of diabetes on patient outcomes after ankle fracture," Journal of Bone and Joint Surgery A, vol. 87, no. 8, pp. 1712-1718, 2005.

[4] American Diabetes Association, "Executive summary: standards of medical care in diabetes-2011," Diabetes Care, vol. 34, supplement 1, pp. S4-S10, 2011.

[5] M. Graves and T. A. Tarquinio, "Diabetic neuroarthropathy (Charcot joints): the importance of recognizing chronic sensory deficits in the treatment of acute foot and ankle fractures in diabetic patients," Orthopedics, vol. 26, no. 4, pp. 415-418, 2003.

[6] M. S. Myerson and W. H. Edwards, "Management of neuropathic fractures in the foot and ankle," The Journal of the American Academy of Orthopaedic Surgeons, vol. 7, no. 1, pp. 818, 1999.

[7] I. Stiell, G. Wells, A. Laupacis et al., "Multicentre trial to introduce the Ottawa ankle rules for use of radiography in acute ankle injuries," British Medical Journal, vol. 311, no. 7005, pp. 594-597, 1995.

[8] S. A. McLaughlin, D. S. Binder, and D. P. Sklar, "Ottawa ankle rules and the diabetic foot," Annals of Emergency Medicine, vol. 32, no. 4, p. 518, 1998.

[9] A. P. Coll, "Ottawa rules, OK? Rules are different in diabetes," British Medical Journal, vol. 339, Article ID b3507, 2009.

[10] M. S. Pinzur, “Transarticular stabilization for malunited fracture of the distal tibia in diabetics with loss of protective sensation," Foot and Ankle International, vol. 22, no. 9, pp. 706-710, 2001.

[11] C. Caravaggi, M. Cimmino, S. Caruso, and S. Dalla Noce, "Intramedullary compressive nail fixation for the treatment of severe Charcot deformity of the ankle and rear foot," Journal of Foot and Ankle Surgery, vol. 45, no. 1, pp. 20-24, 2006.

[12] M. Cinar, A. Derincek, and S. Akpinar, "Tibiocalcaneal arthrodesis with posterior blade plate in diabetic neuroarthropthy," Foot and Ankle International, vol. 31, no. 6, pp. 511-516, 2010.

[13] L. A. DiDomenico, D. Brown, and T. Zgonis, "The use of ilizarov technique as a definitive percutaneous reduction for ankle fractures in patients who have diabetes mellitus and peripheral vascular disease," Clinics in Podiatric Medicine and Surgery, vol. 26, no. 1, pp. 141-148, 2009.

[14] M. A. Ayoub, "Ankle fractures in diabetic neuropathic arthropathy: can tibiotalar arthrodesis salvage the limb?" Journal of Bone and Joint Surgery B, vol. 90, no. 7, pp. 906-914, 2008.

[15] S. Eichenholtz, Charcot Joints, C.C. Thomas, 1966.

[16] E. B. Jude, P. L. Selby, J. Burgess et al., "Bisphosphonates in the treatment of charcot neuroarthropathy: a double-blind randomised controlled trial," Diabetologia, vol. 44, no. 11, pp. 20322037, 2001.

[17] M. S. Pinzur, "Current concepts review: charcot arthropathy of the foot and ankle," Foot and Ankle International, vol. 28, no. 8, pp. 952-959, 2007.

[18] V. R. Prisk and D. K. Wukich, "Ankle Fractures in Diabetics," Foot and Ankle Clinics, vol. 11, no. 4, pp. 849-863, 2006.

[19] W. P. Joyce, K. Walsh, D. B. Gough, T. F. Gorey, and J. M. Fitzpatrick, "Pulse oximetry: a new non-invasive assessment of peripheral arterial occlusive disease," British Journal of Surgery, vol. 77, no. 10, pp. 1115-1117, 1990.

[20] J. J. Guo, H. Yang, Y. Xu, G. Wang, L. Huang, and T. Tang, "Results after immediate operations of closed ankle fractures in 
patients with preoperatively neglected type 2 diabetes," Injury, vol. 40, no. 8, pp. 894-896, 2009.

[21] N. F. SooHoo, L. Krenek, M. J. Eagan, B. Gurbani, C. Y. Ko, and D. S. Zingmond, "Complication rates following open reduction and internal fixation of ankle fractures," Journal of Bone and Joint Surgery A, vol. 91, no. 5, pp. 1042-1049, 2009.

[22] R. G. McCormack and J. M. Leith, "Ankle fractures in diabetics. Complications of surgical management," Journal of Bone and Joint Surgery B, vol. 80, no. 4, pp. 689-692, 1998.

[23] K. B. Jones, K. A. Maiers-Yelden, J. L. Marsh, M. B. Zimmerman, M. Estin, and C. L. Saltzman, "Ankle fractures in patients with diabetes mellitus," Journal of Bone and Joint Surgery B, vol. 87, no. 4, pp. 489-495, 2005.

[24] J. M. Flynn, F. Rodriguez-Del-Río, and P. A. Pizá, “Closed ankle fractures in the diabetic patient," Foot and Ankle International, vol. 21, no. 4, pp. 311-319, 2000.

[25] R. H. Blotter, E. Connolly, A. Wasan, and M. W. Chapman, "Acute complications in the operative treatment of isolated ankle fractures in patients with diabetes mellitus," Foot and Ankle International, vol. 20, no. 11, pp. 687-694, 1999.

[26] B. Kristiansen, "Results of surgical treatment of malleolar fractures in patients with diabetes mellitus," Danish Medical Bulletin, vol. 30, no. 4, pp. 272-274, 1983.

[27] C. Bibbo, S. S. Lin, H. A. Beam, and F. F. Behrens, "Complications of ankle fractures in diabetic patients," Orthopedic Clinics of North America, vol. 32, no. 1, pp. 113-133, 2001.

[28] W. Costigan, D. B. Thordarson, and U. K. Debnath, "Operative management of ankle fractures in patients with diabetes mellitus," Foot and Ankle International, vol. 28, no. 1, pp. 32-37, 2007.

[29] G. B. Holmes Jr. and N. Hill, "Fractures and dislocations of the foot and ankle in diabetics associated with Charcot joint changes," Foot and Ankle International, vol. 15, no. 4, pp. 182185, 1994.

[30] A. J. Kline, G. S. Gruen, H. C. Pape, I. S. Tarkin, J. J. Irrgang, and D. K. Wukich, "Early complications following the operative treatment of pilon fractures with and without diabetes," Foot and Ankle International, vol. 30, no. 11, pp. 1042-1047, 2009.

[31] C. B. White, N. S. Turner, G.-C. Lee, and G. J. Haidukewych, "Open ankle fractures in patients with diabetes mellitus," Clinical Orthopaedics and Related Research, no. 414, pp. 37-44, 2003.

[32] L. C. Schon, M. E. Easley, and S. B. Weinfeld, "Charcot neuroarthropathy of the foot and ankle," Clinical Orthopaedics and Related Research, no. 349, pp. 116-131, 1998.

[33] C. K. Low and S. K. Tan, "Infection in diabetic patients with ankle fractures," Annals of the Academy of Medicine Singapore, vol. 24, no. 3, pp. 353-355, 1995. 


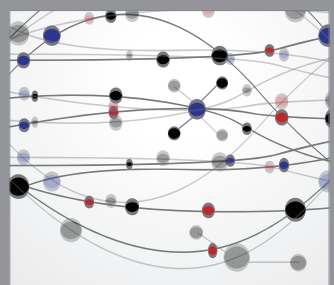

The Scientific World Journal
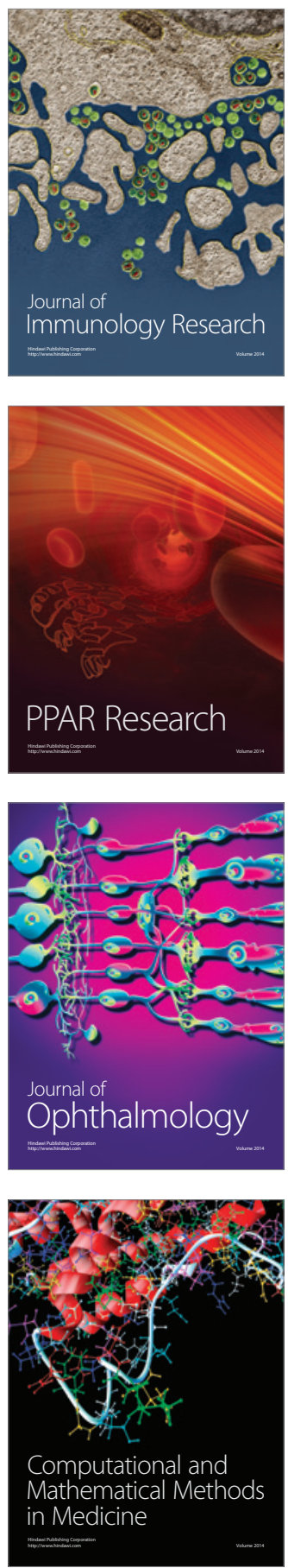

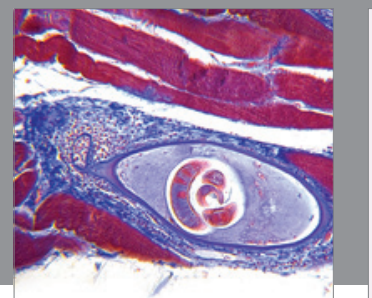

Gastroenterology

Research and Practice
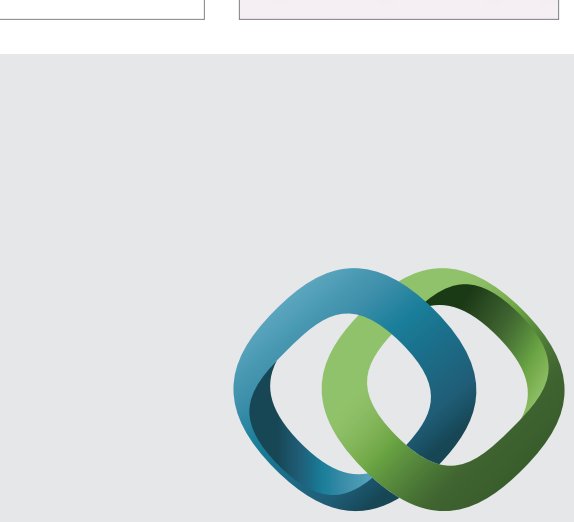

\section{Hindawi}

Submit your manuscripts at

http://www.hindawi.com
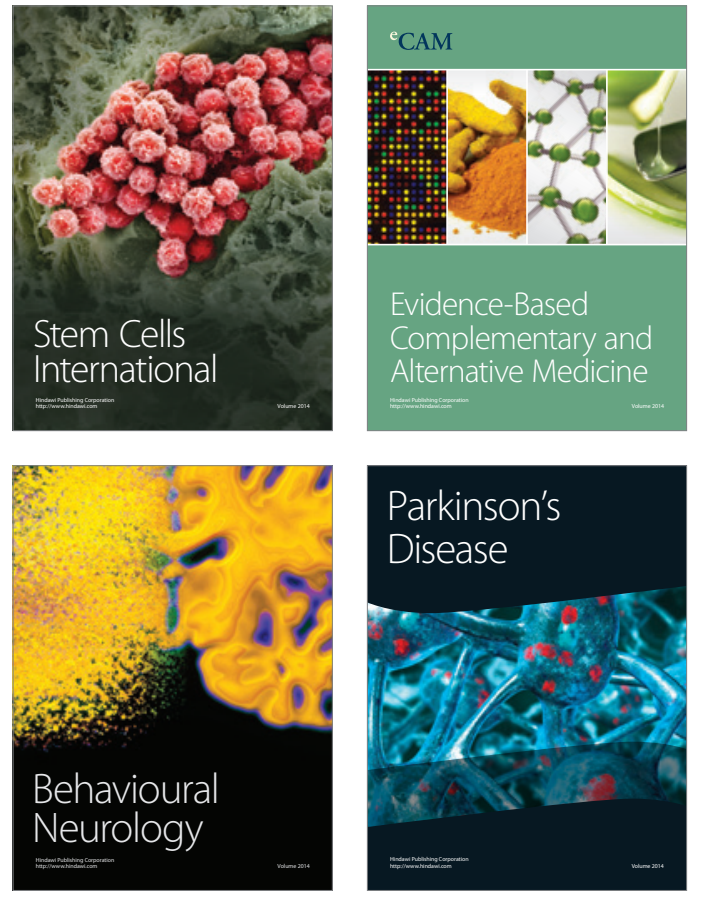
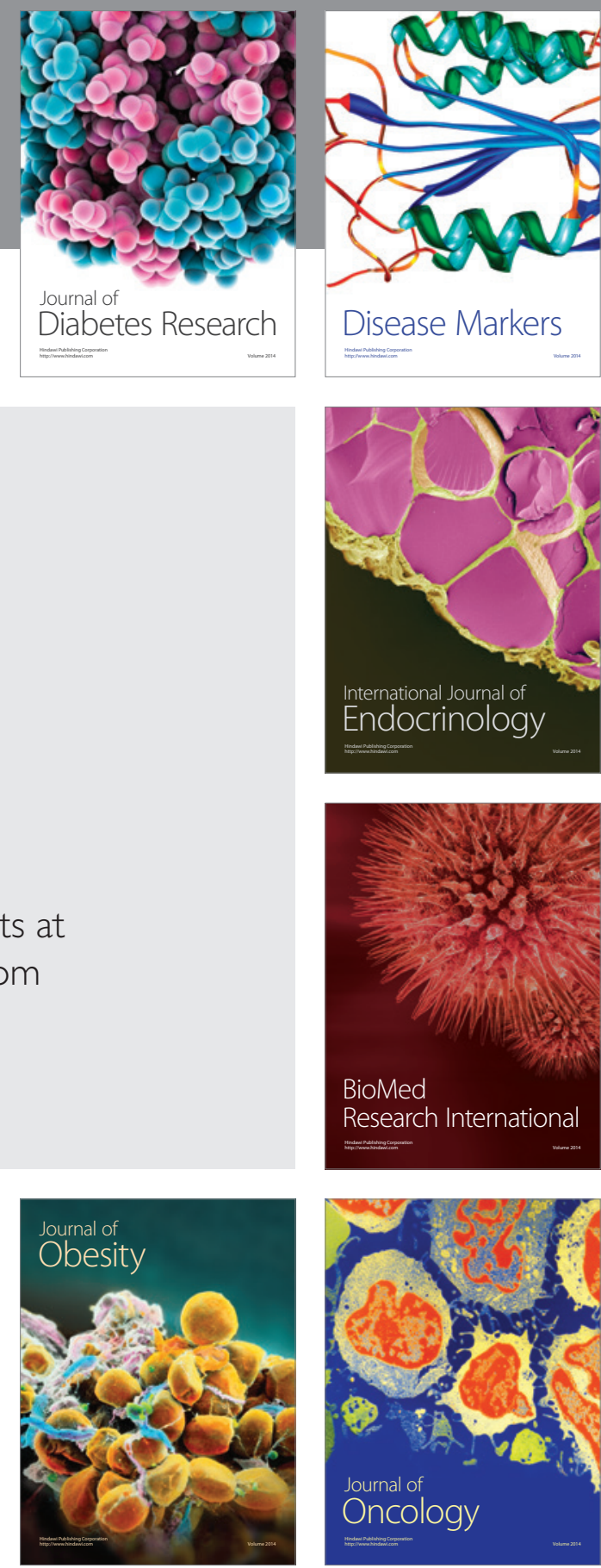

Disease Markers
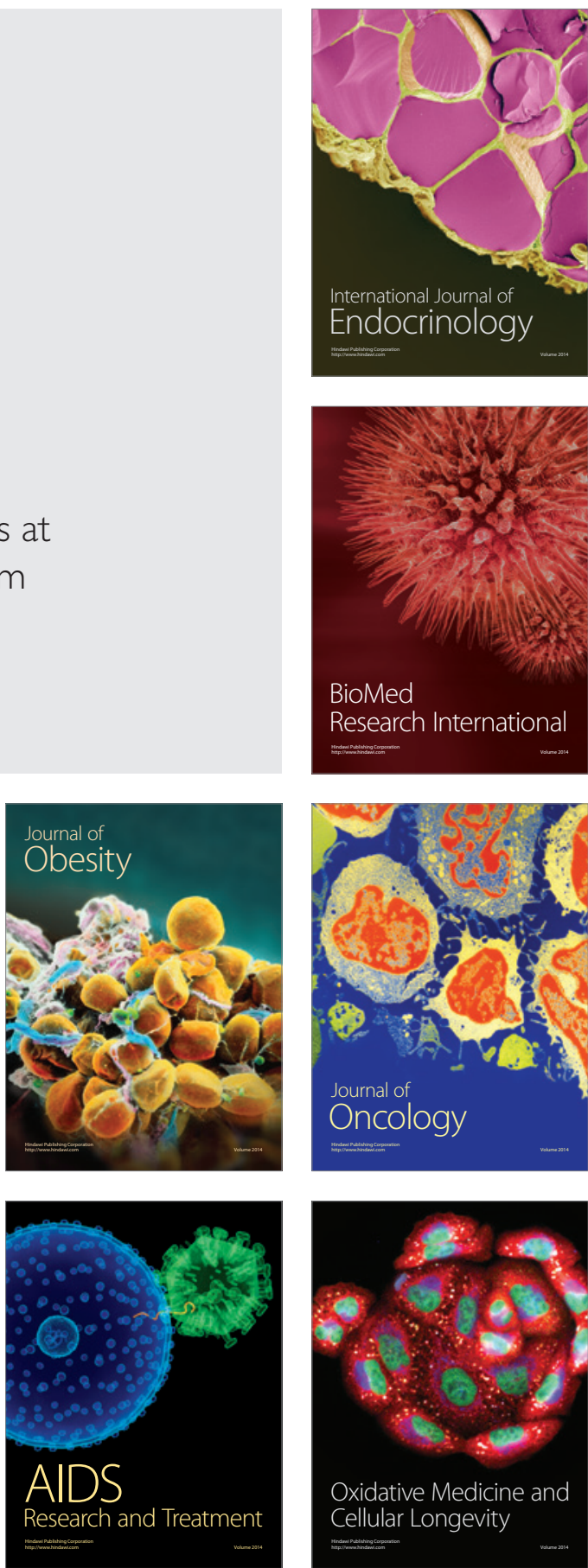